\title{
MODEL PEMBELAJARAN ACTIVE LEARNING DENGAN STRATEGI PENGAJUAN PERTANYAAN UNTUK MENINGKATKAN KUALITAS PROSES PEMBELAJARAN PKn
}

\author{
1Dodik Kariadi \\ 2Wasis Suprapto \\ 11dodik kariadi@yahoo.com \\ 2wasissoeprapto@gmail.com \\ 1,2Program Studi Bimbingan Konseling, STKIP Singkawang, Indonesia
}

\begin{abstract}
Abstrak
Berdasarkan penelitian yang dilakukan maka dapat diperoleh pembelajaran aktif (active learning) dengan strategi pengajuan pertanyaan sebagai model pembelajaran yang paling tepat untuk digunakan pada mata pelajaran PKn di sekolah. Tujuan dari model ini tentu agar siswa menjadi insan yang mampu berpendapat dan berpikir kritis. Dalam penelitian ini, penulis menggunakan penelitian deskriptif-kritis dengan lebih menekankan pada kekuatan analisis sumber-sumber dan data-data yang ada dengan mengandalkan teoriteori dan konsep-konsep yang ada untuk diinterpretasikan berdasarkan tulisan-tulisan yang mengarah kepada pembahasan. Hasil penelitian menunjukkan adanya kepercayaan diri pada siswa, guru lebih terbuka terhadap siswa, dan adanya kompetisi sehat antar-siswa di kelas, semakin meningkatnya antusiasme dan keseriusan siswa, mengurangi kesenjangan pengetahuan antar-siswa, semangat belajar siswa di luar sekolah semakin bertambah, semakin menyadarkan siswa untuk menyukai seluruh mata pelajaran, munculnya ide-ide kreatif baik dari siswa maupun guru dalam rangka memajukan kualitas pendidikan di sekolah masing-masing, dan meningkatkan sinergisitas dan kekompakan antar-siswa maupun antar-guru. Dengan demikian, untuk mewujudkan pembelajaran yang inovatif dapat digunakan karena "model pembelajaran aktif (active learning) dengan strategi pengajuan pertanyaan" sehingga proses pembelajarannya tidak hanya berpusat pada guru, tetapi siswa juga harus terlibat aktif dalam proses pembelajaran sehingga pembelajaran akan menjadi lebih bermakna.
\end{abstract}

Kata kunci: Pembelajaran aktif, pengajuan pertanyaan, kualitas proses.

\begin{abstract}
Based on the research done, in the acquisition of active learning with the strategy of asking questions as the most appropriate learning model to be used on the Civic subjects in school. The purpose of this model is for students to be able to think and think critically. In this study, the author uses descriptive-critical research with more emphasis on the power of analysis of existing sources and data by relying on existing theories and concepts to be interpreted based on the writings that lead to the discussion. The results showed that students 'confidence, teachers are more open to students, The existence of healthy competition among students in the classroom, Increasing the enthusiasm and seriousness of students, Reducing the knowledge gap between students, The students' learning spirit outside school is increasing, like the whole subjects, The emergence of creative ideas from both students and teachers in order to advance the quality of education in each school, and Increase synergy and cohesiveness between students and inter-teachers. Thus, to realize innovative learning, it can be used because "active learning model with questioning strategy" so that the learning process is not only centered on the teacher, but also the students must be actively involved in the learning process so that learning will become more meaningful.
\end{abstract}

Keywords: Active learning, question submission, process quality. 


\section{PENDAHULUAN}

Dewasa ini kita dihadapkan pada berbagai permasalahan pendidikan dan pembelajaran yang hampir tidak pernah berakhir seiring dengan perkembangan peradaban manusia. Demikian halnya dengan Pendidikan Kewarganegaraan (PKn) telah menjadi perhatian dan perdebatan di berbagai negara untuk waktu yang lama. Hal ini tampak dari berbagai badan atau institusi yang dibentuk oleh masing-masing pemerintah untuk menangani masalah ini.

Berkaitan dengan persoalan pendidikan di Indonesia, sepertinya masih banyak sisi-sisi gelap dan sistem pendidikan dan pengajaran di lingkungan kita yang membutuhkan reformulasi konsep dan peninjauan terhadap paradigma pendidikan menuju konsep yang lebih progresif. Dalam konteks ini, konsep pendidikan demokrasi, khususnya dalam sistem pembelajaran di lembaga sekolah, menjadi urgent untuk dicermati secara serius sebagai salah satu upaya menghadapi tantangan masa depan. Dalam konsep demokrasi pendidikan, sesungguhnya terakumulasi prinsip-prinsip bisa diterapkan dalam pelaksanaan pendidikan di Indonesia, yang lebih luas dan lebih bermakna.

Dominasi guru atas murid cenderung masih kuat yang selanjutnya kurang memberikan peluang kepada anak didik untuk menyelesaikan persoalan yang dihadapi. Akibatnya, keluaran lembaga pendidikan terkesan kurang mampu menunjukkan pendirian dan sikap karena sangat terikat dengan pemahaman awal yang diterima tanpa ada sikap kritis dan mempertanyakan apa yang diterimanya. Kondisi itu berlanjut sedemikian rupa sehingga terhadap persoalan masyarakat Indonesia yang semakin kompleks dan berubah secara cepat, tidak/belum mampu dipecahkan para "si terdidik" di negeri ini.

Pembelajaran active learning tampaknya telah menjadi pilihan utama dalam praktik pendidikan saat ini. Di Indonesia, gerakan pembelajaran aktif ini terasa semakin mengemuka bersamaan dengan upaya mereformasi pendidikan nasional, sekitar akhir tahun 90-an. Gerakan perubahan ini terus berlanjut hingga sekarang dan para guru terus menerus didorong untuk dapat menerapkan konsep pembelajaran aktif dalam setiap praktik pembelajaran siswanya.

Beberapa kalangan berpendapat bahwa inti dari reformasi pendidikan ini justru terletak pada perubahan paradigma pembelajaran dari model pembelajaran pasif ke model pembelajaran aktif. Beberapa masalah di atas adalah sedikit dari banyak faktor lain yang memiliki dampak besar dalam mengoptimalkan proses belajar PKn siswa. Kemudian yang menjadi masalah utama untuk dikaji dalam artikel ini adalah bagaiman pemakalah dalam melihat beragai fenomena dalam pembelajaran di kelas terkait dengan model 
Model Pembelajaran Active Learning dengan

Strategi Pengajuan Pertanyaan untuk

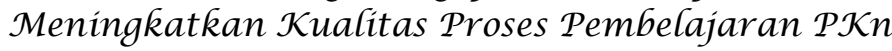

pembelajaran active learning dengan strategi pengajuan pertanyaan untuk meningkatkan kualitas proses pembelajaran Pkn.

\section{METODE PENELITIAN}

Dalam penelitian ini, penulis menggunakan penelitian deskriptif-kritis dengan lebih menekankan pada kekuatan analisis sumber-sumber dan datadata yang ada dengan mengandalkan teori-teori dan konsep-konsep yang ada untuk diinterpretasikan berdasarkan tulisan-tulisan yang mengarah kepada pembahasan. Sumber-sumber tersebut di dapat dari karya yang ditulis oleh intelektual dan ahli yang berkompeten tentang pendidikan yang terdapat dalam daftar pustaka. Proses penelitian dimulai dengan menyusun asumsi dasar dan aturan berpikir yang akan digunakan dalam penelitian. Asumsi dan aturan berpikir tersebut selanjutnya diterapkan secara sistematis dalam pengumpulan dan pengolahan data untuk memberikan penjelasan dan argumentasi berupa pengumpulan dan penyusunan data, serta analisis dan penafsiran data tersebut untuk menjelaskan fenomena dengan aturan berpikir ilmiah yang diterapkan secara sistematis tanpa menggunakan model kuantitatif atau normatif dengan mengadakan klasifikasi, penilaian standar norma, hubungan dan kedudukan suatu unsur dengan unsur lain.

Penelitian ini mendasarkan kepada studi kepustakaan (library research). Library research adalah serangkaian kegiatan yang berkenaan dengan metode pengumpulan data pustaka, membaca dan mencatat serta mengolah bahan penelitiannya. Penelitian ini merupakan suatu penelitian yang memanfaatkan sumber perpustakaan untuk memperoleh data penelitiannya (Mustika Zed, 2004: 2-4). Dalam penjelasannya lebih menekankan pada kekuatan analisis data pada sumber-sumber data yang ada. Sumber-sumber tersebut di peroleh dari berbagai buku dan tulisan-tulisan lainnya dengan mengandalkan teori-teori yang ada untuk diinterpretasikan secara jelas dan mendalam untuk menghasilkan tesis dan anti tesis (Soejono, 1999: 25).

Data yang diperlukan dalam penulisan artikel ini bersifat kualitatif tekstual dengan menggunakan pijakan terhadap statement dan proporsi-proporsi ilmiah yang dikemukakan oleh para pakar pendidikan dan psikologi yang erat kaitannya dengan pembahasan. Dalam penulisan karya ilmiah ini, penulis menggunakan personal dokument sebagai sumber data penelitian ini, yaitu dokumen pribadi yang berupa bahan-bahan tempat orang yang mengucapkan dengan kata-kata mereka sendiri (Furqan, 1992: 23). Personal Document sebagai sumber dasar atau data primernya, dalam hal ini adalah buku-buku yang berkaitan dengan konsepsi dan urgensi pelaksanaan mata pelajaran pendidikan agama Islam dalam pembelajaran tematik yang tentunya merupakan komponen dasar dalam penelitian ini 
Teknik pengumpulan data dengan dokumentasi, mengidentifikasi wacana dari buku-buku, makalah atau artikel, majalah, jurnal, koran, web(internet), ataupun informasi lainnya yang berhubungan dengan judul penulisan untuk mencari hal-hal atau variabel yang berupa catatan, transkip, buku, dan sebagainya yang mempunyai keterkaitan dengan kajian tentang harmonisasi nilai kosmopolitan \& nasionalisme melalui PKn untuk pendidikan berwawasan global berkarakter lokal. Sebagaimana yang diungkapkan oleh Suharsimi Arikunto, metode dokumentasi adalah mencari suatu data mengenai suatu hal atau variabel yang berupa catatan, transkip, buku, surat kabar, majalah, prasasti-prasasti, notulen rapat, agenda dan sebagainya (Arikunto, 2002: 83). Hal ini dilakukan dengan analisis wacana (discourse analysis) supaya tidak tumpang tindih dalam melakukan analisa.

Dalam penelitian ini, setelah data terkumpul maka data tersebut dianalisis untuk mendapatkan konklusi, bentuk-bentuk dalam teknik analisis deskriptif. Analisis deskriftif yaitu usaha untuk mengumpulkan dan menyusun suatu data, kemudian dilakukan analisis terhadap data tersebut (Winarno, 1990: 139). Pendapat analisis data deskriptif tersebut adalah data yang kumpulkan berupa kata-kata dan gambar bukan dalam bentuk angka-angka, hal ini disebabkan oleh adanya penerapan metode kualitatif. Selain itu, semua yang dikumpulkan kemungkinan menjadi kunci terhadap apa yang sudah diteliti (Moleong, 2002: 16). Dengan demikian, laporan penelitian akan berisi kutipan-kutipan data untuk memberi gambaran penyajian laporan tersebut.

Kajian ini, di samping itu dengan cara analisis isi dapat dibandingkan antara satu buku dengan buku yang lain dalam bidang yang sama, baik berdasarkan perbedaan waktu penulisannya maupun mengenai kemampuan buku-buku tersebut dalam mencapai sasaran sebagai bahan yang disajikan kepada masyarakat atau sekelompok masyarakat tertentu. Kemudian data kualitatif tekstual yang diperoleh dikatagorikan dengan memilah data tersebut. Sebagai syarat yang dikemukakan oleh Noeng Muhajir tentang Content Analysis yaitu, objektif, sistematis, dan general (Muhaji, 1906: 69).

Metode Pembahasan untuk mempermudah dalam penulisan ini, maka sangat diperlukan untuk menggunakan pendekatan-pendekatan yaitu: 1) Metode induktif adalah berangkat dari fakta-fakta atau peristiwa-peristiwa khusus dan kongkrit, kemudian digeneralisasikan menjadi kesimpulan yang bersifat umum. 2) Metode deduktif adalah metode yang berangkat dari pengetahuan yang bersifat umum itu hendak menilai sesuatu kejadian yang sifatnya khusus. 3) Metode komparasi adalah meneliti faktor-faktor tertentu yang berhubungan dengan situasi atau fenomena yang diselidiki dan membandingkan satu faktor dengan yang lain, dan penyelidikan bersifat komparatif (Winarno, 1990: 139). 
Model Pembelajaran Active Learning dengan

Strategi Pengajuan Pertanyaan untuk

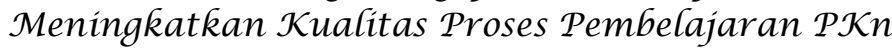

\section{HASIL DAN PEMBAHASAN}

Proses pembelajaran pada dasarnya merupakan pemberian stimulusstimulus kepada anak didik, agar terjadinya respons yang positif pada diri anak didik. Kesediaan dan kesiapan mereka dalam mengikuti proses demi proses dalam pembelajaran akan mampu menimbulkan respons yang baik terhadap stimulus yang mereka terima dalam proses pembelajaran. Respons akan menjadi kuat jika stimulusnya juga kuat. Ulangan-ulangan terhadap stimulus dapat memperlancar hubungan antara stimulus dan respons, sehingga respons yang ditimbulkan akan menjadi kuat. Hal ini akan memberi kesan yang kuat pula pada diri anak didik, sehingga mereka akan mampu mempertahankan respons tersebut dalam memory (ingatan) nya.

Hubungan antara stimulus dan respons akan menjadi lebih baik kalau dapat menghasilkan hal-hal yang menyenangkan. Efek menyenangkan yang ditimbulkan stimulus akan mampu memberi kesan yang mendalam pada diri anak didik, sehingga mereka cenderung akan mengulang aktivitas tersebut. Akibat dari hal ini adalah anak didik mampu mempertahan stimulus dalam memory mereka dalam waktu yang lama (longterm memory), sehingga mereka mampu merekam apa yang mereka peroleh dalam pembelajaran tanpa mengalami hambatan apapun.

Dalam model pembelajaran aktif active learning setiap materi pelajaran yang baru harus dikaitkan dengan berbagai pengetahuan dan pengalaman yang ada sebelumnya. Materi pelajaran yang baru disediakan secara aktif dengan pengetahuan yang sudah ada. Agar murid dapat belajar secara aktif guru perlu menciptakan strategi yang tepat guna sedemikian rupa, sehingga peserta didik mempunyai motivasi yang tinggi untuk belajar. (Mulyasa, 2004:241)

Winastwan Gora \& Sunarto (2010: 10) menjelaskan bahwa, active learning adalah suatu istilah yang memayungi beberapa model pembelajaran yangmemfokuskan tanggung-jawab proses pembelajaran pada si pelajar. Sedangkan Joel Wein (Winastwan Gora, 2010: 11) menjelaskan bahwa, active learning adalah nama suatu pendekatan untuk mendidik para siswa dengan memberikan peran yang lebih aktif di dalam proses pembelajaran. Unsur umum di dalam pendekatan ini adalah bahwa guru dipindahkan peran kedudukannya, dari yang paling berperan di depan suatu kelas dan mempresentasikan materi pelajaran, menjadi para siswalah yang beradapada posisi pengajaran diri mereka sendiri, dan guru diubah menjadi seorang pelatih dan penolong di dalam proses itu.

Silberman (2010: 5) mengatakan saat belajar aktif, para siswa melakukan banyak kegiatan. Mereka menggunakan otak untuk mempelajari ide-ide, memecahkan masalah dan menerapkan apa yang mereka pelajari. Belajar aktif adalah mempelajari dengan cepat, menyenangkan, penuh semangat dan keterlibatan secara pribadi untuk mempelajari sesuatu yang baik. Selain itu 
siswa harus mendengar, melihat, menjawab pertanyaan dan mendiskusikannya dengan orang lain. Semua itu diperlukan oleh siswa untuk melakukan kegiatan menggambarkannya sendiri, mencontohkan, mencoba keterampilan dan melaksanakan tugas sesuai dengan pengetahuan yang mereka miliki. Dengan demikian belajar aktif dapat memperkuat dan memperlancar stimulus dan respon siswa dalam pembelajaran.

Modell \& Michael (1993) Menggambarkan suatu lingkungan belajar aktif adalah lingkungan belajar dimana para siswa secara individu didukung untuk terlibat aktif dalam proses membangun model mentalnya sendiri dari informasi yang telah mereka peroleh. Joel Wein (1997:1) mendefinisikan active learning adalah nama suatu pendekatan untuk mendidik para siswa dengan memberikan peran yang lebih aktip di dalam proses pembelajaran. Unsur umum di dalam pendekatan ini adalah bahwa guru dipindahkan peran kedudukannya dari yang paling berperan depan suatu kelas dan mempresentasikan materi pelajaran menjadi para siswa lah yang berada pada posisi pengajaran diri mereka sendiri, dan guru diubah menjadi seorang pelatih dan penolong di dalam proses itu.

Belajar aktif adalah suatu pendekatan dalam pengelolaan sistem pembelajaran melalui cara-cara belajar yang aktif menuju belajar yang mandiri. Kemampuan belajar mandiri ini merupakan tujuan akhir dari belajar aktif (Eveline \& Hartini, 2010: 106). Untuk dapat mencapai hal tersebut kegiatan pembelajaran dirancang sedemikian rupa agar bermakna bagi siswa atau anak didik. Pembelajaran aktif dimaksudkan untuk mengoptimalkan penggunaan semua potensi yang dimiliki oleh anak didik, sehingga semua anak didik dapat mencapai hasil belajar yang memuaskan, selain itu untuk menjaga perhatian siswa atau anak didik agar tetap fokus pada proses pembelajaran. Belajar yang bermakna terjadi apabila siswa atau anak didik berperan secara aktif dalam proses belajar dan akhirnya mampu memutuskan apa yang akan dipelajari dan cara mempelajarinya.

Dari beberapa pendapat tersebut dapat ditarik kesimpulan bahwa model active learning menurut makalah ini adalah suatu model pembelajaran yang memberikan kesempatan kepada siswa untuk berperan lebih aktif dalam proses pembelajaran (mencari informasi, mengolah informasi, dan menyimpulkannya untuk kemudian diterapkan atau dipraktikkan) dengan menyediakan lingkungan belajar yang membuat siswa tidak tertekan dan senang melaksanakan kegiatan belajar.

Dalam proses pembelajaran setiap siswa memiliki kelebihan dan kekurangan untuk menguasai materi. Ada siswa yang cepat, sedang, bahkan lambat dalam menyerap materi yang disampaikan. Biasanya tidak semua siswa menangkap apa yang dijelaskan oleh guru. Karena itu guru mengharapkan partisipasi siswa dalam menyampaikan pertanyaan mengenai materi yang belum dipahaminya. 
Model Pembelajaran Active Learning dengan

Strategi Pengajuan Pertanyaan untuk

$\mathcal{M}$ eningkatkan Kualitas Proses Pembelajaran $\mathcal{P} \mathcal{K} n$

Untuk itu diperlukan suatu upaya dalam rangka meningkatkan mutu pendidikan dan pengajaran. Salah satunya adalah dengan memilih strategi atau cara dalam menyampaikan materi pelajaran agar diperoleh peningkatan prestasi belajar siswa khususnya pada mata pelajaran PKn. Misalnya dengan membimbing siswa untuk bersama-sama terlibat aktif dalam proses pembelajaran dan mampu membantu siswa berkembang sesuai dengan taraf intelektualnya akan lebih menguatkan pemahaman siswa terhadap konsepkonsep yang diajarkan.

Dari uraian di atas, maka salah satu upaya yang dianggap dapat memecahkan masalah tersebut adalah dengan menggunakan strategi pembelajaran Aktif tipe "strategi pengajuan pertanyaan" yang diharapkan melibatkan siswa secara aktif dalam pembelajaran PKn. Oleh karena itu perlu diamati dengan penerapan langsung di kelas. Untuk menyelidiki hal tersebut dalam makalah ini akan diuraikan hal-hal penting yang terkait dengan konsep ini.

Ada beberapa alasan mendasar mengapa mengapa strategi pembelajaran aktif tipe strategi pengajuan pertanyaan sebagai solusi yang tepat dalam untuk meningkatkan kualitas proses pembelajaran PKn. a. Strategi pembelajaran aktif tipe strategi pengajuan pertanyaan merupakan strategi pembelajaran yang memiliki karakteristik sebagai berikut: 1) Strategi pembelajaran ini memberikan ruang privacy siswa untuk menuliskan pertanyaan berisi masalah yang dihadapi saat proses pembelajaran. 2) Pertanyaan yang dimiliki siswa dengan tingkat kesamaan yang tinggi akan dibahas bersama-sama. 3) Sebelum guru menjawab pertanyaan, guru memberikan kesempatan bagi siswa yang mampu menjawab pertanyaan-pertanyaan tersebut. 4) Pertanyaan siswa yang tidak sama dengan siswa lain akan dibahas jika waktu masih tersedia. Jika waktu telah habis,pertanyaan akan dijawab pada pertemuan selanjutnya, dan. 5) Strategi pembelajaran ini membuat siswa sering berlatih dan berpikir dalam menjawab pertanyaan. b. Strategi pembelajaran aktif tipe "strategi pengajuan pertanyaan" melibatkan siswa untuk turut aktif dalam proses pembelajaran dengan mengajukan pertanyaan dan menyelesaikan masalah PKn.

Pembelajaran active learning melalui strategi pengajuan pertanyaan" yang telah dikembangkan oleh Melvin L Silberman. Strategi ini digunakan untuk mempelajari tentang keinginan dan harapan anak didik sebagai dasar untuk memaksimalkan potensi yang mereka miliki dalam bentuk pertanyaan yang dituliskan pada kartu tanya. Strategi ini menggunakan sebuah teknik untuk mendapatkan partisipasi siswa (Silberman, 2013: 91). Sangat baik digunakan pada peserta didik yang kurang berani mengungkapkan pertanyaan dan memberikan kesempatan siswa untuk mengeksplorasikan keterampilannya. Tidak terlepas dari peran guru sebagai fasilitator, informator, dan motivator. 
Strategi Pembelajaran tipe "strategi pengajuan pertanyaan" adalah salah satu tipe instruksional dari belajar aktif (active learning) yang termasuk dalam bagian Collaborative learning (belajar dengan cara bekerja sama) yang bertujuan melatih kemampuan bekerja sama, melatih kemampuan mendengarkan pendapat orang lain, peningkatan daya ingat terhadap materi yang dipelajari, melatih rasa peduli dan kerelaan untuk berbagi, menumbuhkan rasa penghargaan terhadap orang lain, melatih kecerdasan emosional, mengasah kecerdasan interpesonal, meningkatkan motivasi dan suasana belajar serta kecepatan dan hasil belajar dapat lebih meningkat.

Model pembelajaran aktif (active learning) dengan strategi pengajuan pertanyaan" adalah metode pembelajaran interaktif dua arah antara guru dengan siswa dan sebaliknya, yang tentunya metode ini menggunakan sebuah aturan baku bahwa setiap siswa harus bertanya, artinya seluruh siswa yang terlibat dalam sebuah proses pembelajaran di kelas pada hari itu harus mengajukan sebuah pertanyaan tentang hal-hal yang berkaitan/berhubungan dengan materi yang dipelajari, tidak terkecuali bagi siswa yang merasa telah memahami materi. Hal ini di terapkan karena dalam penyampaian belajar guru cenderung dominan bertanya kepada siswa, ini lakukan tidak untuk seluruh siswa melainkan ditunjuk langsung berdasarkan evaluasi yang ada. Tentu sistem acak dan perkiraan seperti ini tidak akan dapat mengevaluasi kualitas proses belajar PKn setiap siswa.

Berikut beberapa langkah-langkah yang pemakalah buat dalam penerapan "model pembelajaran aktif (active learning) dengan strategi pengajuan pertanyaan" yang harus diaplikasikan supaya proses terbaik yang diharapkan berjalan secara maksimal, yaitu: 1) Guru menyampaikan/menguraikan materi pembelajaran secara sistematis dan etis terhadap siswa. 2) Setelah itu, guru mengalokasikan waktu khusus untuk memberikan kesempatan kepada setiap siswa untuk bertanya. Seluruh siswa wajib mengajukan pertanyaan mengenai materi pelajaran yang telah disampaikan tak terkecuali bagi siswa yang merasa telah menguasai materi saat itupun tetap harus bertanya, tentunya tentang halhal yang masih ada keterkaitan atau hubungan dengan materi itu. Hal ini dilakukan dengan tujuan agar mereka yang telah memahami materi pokok dalam pembelajaran saat itu akan mendapatkan penguasaan materi pembelajaran yang lebih komprehensif sekaligus sebagai wacana baru mereka, selain itu juga akan dapat dijadikan sebagai referensi ataupun bahan berpikir tambahan dalam proses pemahaman bagi siswa lainnya yang belum menguasai materi tersebut. 3) Bila ternyata pada sesi khusus di atas tidak ada pertanyaan dari siswa, maka guru dapat memberikan pertanyaan kepada setiap siswa satu demi satu, seluruh siswa dalam satu kelas mendapatkan pertanyaan dalam sesi ini, hal ini dilakukan guru untuk memastikan bahwa seluruh siswa benar-benar memahami pelajaran yang telah dipelajarinya saat itu. Langkah ini sebagai 
Model Pembelajaran Active Learning dengan

Strategi Pengajuan Pertanyaan untuk

Meningkatkan Kualitas Proses Pembelajaran PKn

bahan evaluasi lanjutan. 4) Apabila didapati salah satu atau beberapa siswa yang tidak dapat menjawab pertanyaan guru, maka siswa tersebut dipersilahkan untuk maju ke depan kelas. Hal ini akan menjadi sanksi yang positif bagi siswa tersebut untuk mengasah kepercayaan diri mereka dalam lingkungan kelasnya serta memicu siswa lainnya untuk lebih serius dalam belajarnya, sebab masih banyak ditemukan beberapa anak malu mengakui kekurangannya dihadapan siswa lainnya sehingga siswa itupun segan untuk bertanya. Selanjutnya siswa tersebut tidak diperkenankan duduk kembali sebelum ia dapat menjawab pertanyaan dari guru dan atau setelah ia mengajukan sebuah pertanyaan yang berhubungan dengan materi saat itu, inipun tentu berdasarkan pertimbangan guru yang bersangkutan akan ketersediaan waktu yang cukup serta pertimbangan moril lainnya. Hal inipun dilakukan dengan tujuan utama yakni untuk penanaman mental positif bagi anak dalam upaya menghilangkan kesan bahwa bertanya itu kelihatan bodohnya, namun bertanya itu justru menunjukkan akan kemauan pintarnya. 5) Membuat daftar hasil evaluasi belajar dan tindak lanjut proses pembelajaran bagi siswa pada pertemuan belajar selanjutnya. Jika diperlukan penambahan alokasi waktu bertanya dan ditanya dari setiap siswa kepada guru maupun sebaliknya ini dapat dilanjutkan pada pertemuan selanjutnya.

Dalam penerapannya saya akan menguraikan langkah-langkah terperinci dari penerapan "model pembelajaran aktif (active learning) dengan strategi pengajuan pertanyaan". Total waktu yang dialokasikan selama 80 menit (40 x 2 jam pelajaran) dengan rincian pembagian alokasi waktu: 1) Menyampaikan kutipan materi PKn pada pokok bahasan yang telah ditentukan dengan memberikan alokasi waktu \pm 30 menit. 2) Setelah materi disampaikan pada seluruh siswa, kemudian mengalokasikan waktu khusus selama \pm 17 menit untuk mempersilahkan siswa bertanya kepada guru, selanjutnya langsung menjawab seluruh pertanyaan-pertanyaan siswa tersebut langsung satupersatu setelah mereka selesai dalam menyampaikan pertanyaannya, dan ternyata tidak ada satupun siswa yang tidak bertanya, karena dari awal sesi ini telah kita umumkan pada seluruh siswa bahwa semua siswa harus bertanya pada kita selaku guru tentang semua hal yang berkaitan dengan pembahasan materi pada hari itu, bila tidak, nanti kita akan balik bertanya pada siswa, dan bila siswa tidak bisa menjawab, maka siswa tersebut mendapatkan sanksi dengan berdiri di depan kelas, dan ia akan boleh duduk kembali setelah siswa dapat menjawab pertanyaan dari kita, tentunya konten (isi) dari pertanyaan kita juga berkaitan dengan materi yang telah kita sampaikan pada hari itu. 3) Langkah selanjutnya adalah mengalokasikan waktu \pm 5 menit untuk sesi penyegaran belajar di kelas dengan mempersilahkan siswa yang ingin buang air kecil, pada sesi ini dapat diisi pula dengan cerita-cerita singkat namun lucu (menghibur), yang dapat menginspirasi sekaligus dapat memotivasi siswa 
untuk senantiasa bersemangat dalam belajar atau dapat diisi pula dengan tebakan-tebakan lucu yang cerdas, hal ini untuk kembali menyegarkan semangat anak dalam membuka cakrawala berpikir positif mereka. 4) Kemudian alokasi waktu \pm 17 menit yang seharusnya digunakan untuk sesi guru bertanya dengan siswa ditiadakan, karena sesi ini dapat digunakan apabila seluruh siswa atau beberapa siswa tidak bertanya pada sesi sebelumnya. Oleh karena itu, alokasi waktu yang tersedia \pm 17 menit ini dapat dijadikan guru untuk pendalaman materi pada hari itu. 5) Pada sesi terakhir, tersisa alokasi waktu \pm 11 menit untuk penyampaian kesimpulan guru, evaluasi belajar pada hari itu, penyampaian pengumuman (bila ada), nasehat guru, dan penutupan.

Kesimpulan: Setelah menerapkan "model pembelajaran aktif (active learning) dengan strategi pengajuan pertanyaan" ini, akan diperoleh banyak manfaat-manfaat positif yang akan diperoleh baik oleh guru sendiri dan seluruh siswa akan merasakan, hal-hal positif antara lain: 1) Kepercayaan diri siswa semakin meningkat. 2) Guru lebih terbuka terhadap siswa untuk terus mau belajar dalam rangka meningkatkan kualitas pembelajarannya dengan penguasaan ilmu yang komprehensif tentunya. 3) Adanya kompetisi sehat antar-siswa di kelas. 4) Semakin meningkatnya antusiasme dan keseriusan siswa dalam memperhatikan seluruh materi yang sedang disampaikan oleh guru di kelas. 5) Mengurangi kesenjangan pengetahuan antar-siswa, 6) Semangat belajar siswa di luar sekolah semakin bertambah. 7) Semakin menyadarkan siswa untuk menyukai seluruh mata pelajaran atau bidang studi yang dipelajari di sekolah, karena pada dasarnya seluruh materi pelajaran ada hubungan erat antara satu dengan yang lainnya. 8) Munculnya ide-ide kreatif baik dari siswa maupun guru dalam rangka memajukan kualitas pendidikan di sekolah masing-masing. 9) Meningkatkan sinergitas dan kekompakan antarsiswa maupun antar-guru.

Selain hal-hal tersebut di atas, tentu masih banyak manfaat-manfaat positif lainnya ke depan, karena "model pembelajaran aktif (active learning) dengan strategi pengajuan pertanyaan" ini kita harapkan terus kembangkan serta inovasikan demi peningkatan kualitas pendidikan di sekolah masing-masing rangka mewujudkan SDM yang berkualitas serta cerdas dengan metode-metode pembelajaran yang berkualitas dan cerdas pula.

\section{SIMPULAN}

Keaktifan mahasiswa dalam proses interaksi pembelajaran secara umum berkaitan erat dengan menarik dan tidaknya proses kegiatan pembelajaran. karena "model pembelajaran aktif (active learning) dengan strategi pengajuan pertanyaan" menuntut kreativitas dan inovasi dari guru. Proses pembelajaran aktif (active learning) dengan strategi pengajuan pertanyaan yang dibangun dengan mendorong keaktifan belajar siswa, tentunya akan mampu mendorong 
Model Pembelajaran Active Learning dengan

Strategi Pengajuan Pertanyaan untuk

Meningkatkan Kualitas Proses Pembelajaran PKn

keterlibatan siswa dalam setiap langkah pembelajaran. Terjadinya peningkatan keaktifan mahasiswa dalam seluruh rangkaian kegiatan pembelajaran mengindikasikan bahwa proses pembelajaran telah berlangsung secara berkualitas. Dengan terciptanya proses pembelajaran yang berkualitas, pada akhirnya juga akan berpengaruh terhadap hasil pembelajaran yang lebih baik.

Untuk mewujudkan pembelajaran yang inovatif maka dapat digunakan karena "model pembelajaran aktif (active learning) dengan strategi pengajuan pertanyaan" sehingga proses pembelajarannya tidak hanya berpusat pada guru, tetapi siswa juga harus terlibat aktif dalam proses pembelajaran sehingga pembelajaran akan menjadi lebih bermakna. Dibutuhkan kecakapan guru dalam mengendalikan kelas, keaktifan siswa dalam proses belajar, waktu dan fasilitas pendukung yang memadai dalam penerapan pembelajaran aktif.

Semoga dengan makalah yang telah dibuat ini dapat memberi tambahan pengetahuan terkait karena "model pembelajaran aktif (active learning) dengan strategi pengajuan pertanyaan"sehingga guru dapat memilih dan menerapkannya dengan baik dalam pembelajaran yang lebih inovatif dan bermakna.

\section{DAFTAR PUSTAKA}

Hamruni. (2012). Strategi Pembelajaran. Yogyakarta: Insan Madani John wiley \& Sons, Inc. Muijs, D. \& Reynolds, D. (2008). Effective Teaching: Teori dan Aplikasi. Yogyakarta: Pustaka Pelajar.

Meyers, C. \& Jones, T.M. (1993). Promoting Active Learning Strategies for The College Classroom.

Mulyasa, E. (2004). Kurikulum Berbasis Kompetensi (KBK), Konsep, Karakteristik dan Implementasi. Bandung: Remaja Rosdakarya.

Sanjaya, W. (2007). Strategi Pembelajaran Berorientasi Standar Proses Pendidikan. Jakarta: Kencana.

Semiawan, C. (1999). Pendidikan Tinggi, Peningkatan Kemampuan Manusia Sepanjang Hayat Seoptimal Mungkin. Jakarta: Depdikbud Dirjen Dikti.

Silberman, M.L. (2006). Active Learning: 101 Strategi Pembelajaran Aktif (terjemahan). Bandung: Nuansa

Siregar, Eveline \& Hartini Nara. (2010). Teori Belajar dan Pembelajaran. Jakarta: Ghalia Indonesia.

Sudjana, Nana. (1996). Cara Belajar Siswa Aktif dalam Proses Belajar Mengajar. Bandung: Sinar Baru Algensindo Offset.

Zaini, Hisyam. (2008). Strategi Pembelajaran Aktif. Yogyakarta: Pustaka Insan Madani. 